\title{
THE USE OF DIFFERENTIATION STAINING OF BONE ON ANATOMIC PREPARATIONS
}

\author{
C. ČERVENÝ \\ Department of Morphology, University of Veterinary Science, 61242 Brno
}

Received Fanuary 25, 1978

\begin{abstract}
Cervený C.: The Use of Differentiation Staining of Bone on Anatomic Preparations. Acta vet. Brno, 48, 1979: 3-7.

The method proposed for staining bone tissue on macroscopic anatomic preparations (Červený 1972) was tested and applied for investigations of topographic anatomy, macrostructure of bones in ontogenesis, and for demonstration purposes in lectures on normal anatomy of mammalian skeletons. Attention was drawn to the possible use of this method for studies of the individual body regions. Using this method objective preparations can be gained of the bone macrostructure and whole topographic parts of the skeleton for lectures in normal mammalian anatomy. A series of preparations can be prepared giving the developmental changes of the structure of the skeleton, even in combination with roentgenography. Differential staining of bones can also be used for colour photographs.
\end{abstract}

Bone, cattle, pigs, dogs, topographic sections.

For purpose of easy and clear orientation it is very convenient to use the conventional methods of staining animal tissues on anatomic preparations and topographic macrosections. Very successful for instruction on the anatomy of the central nervous system is differentiation staining of the grey matter of the brain and spinal cord according to Mulligan (1931) as well as the classical tinction methods of cartilage and bone in combination with clarification when demonstrating the ossification centres of the developing skeleton (Johnson 1933; Williams 1943; Hood and Neil 1948). In studies of anatomic topographic sections and in studies of the macrostructure and development of the individual bones of the skeleton some problems are encountered of macroscopic differentiation of the individual connective tissues. That is why a method of surface staining of the bone tissue was elaborated (Červený 1972); in this method the red stained bone clearly contrasts with the white colour of the periosteum, articular cartilage and growth zones, and bone marrow. Alizarin red - sodium alizarine monosulphate (Lachema, CSSR) - was used as differentiation stain. The staining affinity of alizarin to the bone is excellent and this colouring agent, formerly obtained from the root of the safflower and now produced synthetically, was used in studies of the growth of animal bones (Brash 1924; Dživanjan 1964) and in histochemical methods of studies of calcium in tissue (Lillie 1965; Puchtler et al. 1969).

In this study results are given of surface staining of bones using alizarin (Červený 1972) giving also a proposal of applying the method in studies of the development of mammalian skeletons and in lectures on anatomy.

\section{Materials and Methods}

The material elaborated includes either individual bones of cattle, pig and dog skeletons or topographic macrosections of the body regions or the individual bones prepared using a rotary bone saw. When staining the surface of whole bones it is necessary to peel off the periosteum. Fresh frozen topographic sections were processed in 4\% formaldehyde for $2-3$ days and then transferred to $75 \%$ ethylalcohol denatured with $2 \%$ of petrol. The material prepared in this way was then subjected to a staining process for differentiation staining of the bone tissue with alizarin red (Cervený 1972). In order to obtain a better colour contrast on the anatomic prepa- 
rations the period of staining can be extended from 24 hours to as much as 3 days and/or the concentration of the staining solution can be increased to $0.01 \%$. A deeper colouring of the bone tissue increases the colour contrast of bones as compared with other connective tissues. If alizarin red penetrates into the cartilage as well, then it decolourizes in the final bath (75\% ethylalcohol denatured with $2 \%$ of petrol). The stained sections are put into $75 \%$ ethylalcohol denatured with $2 \%$ of petrol where eventually the differentiation of the red staining of the bone really improves. Finished preparations for demonstrations are fitted into measuring cells into either $75 \%$ ethylalcohol denatured with $2 \%$ of petrol or into $4 \%$ formaldehyde. Both preserving solutions should be modified to $\mathrm{pH} 9$ by adding soda lye.

\section{Results}

Staining of bone tissue using alizarin red contributes to a strong colour differentiation of the bone tissue. The contrast in colour is best seen on bone macrosections. Very good is the contrast between the red spongy trabeculae of the bone and white colour of the preserved bone marrow (Fig. 1). Staining of the compact bone is homogenous and less intensive. The periosteum and articular cartilage as well as cartilages of growth zones and connective tissue remain white. Using the method it is possible to detect also the extent of primary and secondary ossification centres seen in the plane of the section in juvenile animals or foetuses. The parts stained deeper red on the sections correspond also with their stronger clarification on a roentgenogram of the bone studied.

This method can be used for increasing the contrast of topographic anatomic sections, for both research and instruction purposes. On sagittal sections of the spines of young animals elaborated using differentiation staining of bone tissue with alizarin red (Fig. 2) the white intervertebral discs are seen to contrast very well with the red coloured vertebral corpora. On the bodies of the vertebrae we can study also the arrangement of the bone spongiosa, marrow cavities and/or cartilages of growth zones and secondary ossification centres of vertebral corpora or vertebral spinae. In an age series the developmental changes in the skeleton arrangement can be followed. On the sagittal section of the sacral bone of a juvenile pig (Fig. 4), for example, evident are accretions of the sacral vertebral corpora so that the intervertebral discs have either disappeared or only their residue can be found. The cartilages of growth zones between the primary and secondary centres of the vertebral corpora are well developed and using this method they are distinct on the sections. In young calves, on the level of the caudal spine the primary and cranial and caudal secondary ossification centres of the individual vertebrae are evident on the sagittal sections stained according to this method. On the sagittal section of the sternum stained according to this method (Fig. 5) the red coloured sternebrae become prominent as compared with the cartilaginous parts of the sternum, and also the intersternal articular joint. When using this method we can differentiate in colour the connection of the sternal cartilage on the longitudinal section of the rib in the distal segment to the distal bony end of the rib and/or to detect the calcified segments of the cartilage.

On the sagittal sections of the head of juvenile animals the method of differentiation staining of bone tissue using alizarin red can be used for differentiating the corpora of the individual bones of the basicranial axis: os occipitale, os basisphenoidale and os praesphenoidale, and between them the cartilages of growth zones. On the sagittal section they contrast in colour with the white cartilage of the nasal septum lamina perpendicularis ossis ethmoidalis and in the pig in the rostral part of the nasal septum os rostrale. On the transversal sections of the head (Fig. 6) we can well differentiate the white connective tissue of the cranial sutures at 
the margins of the individual red stained bones, and also the relationships between the teeth roots and the alveoli. The bone of the teeth alveoli, cementum and dentin are stained red with alizarin, while the periodontium and enamel with gums remain white. Dentin immediately demarcating the pulp chamber of the tooth and dentin forming a star on the facies occlusalis of the teeth is stained very intensively. On the cross sections of the nasal cavity the bony lamellae of the olfactory and nasal conchae are well differentiated in colour, the vomer and cartilaginous nasal septum with the bones surrounding the nasal cavity and the mucous surface of the nasal and oral cavities contrast well in colour.

The differentiation staining method using alizarin red was applied for the extremities both on sagittal and transversal sections of the individual isolated bones and on topographic sections of the whole extremities or their individual regions. On sagittal sections of the long bones of extremities from young animals the spongiosa of the epiphyses and ends of the bone diaphysis with a closed cartilage of the growth zone is well evident after staining. The bone trabeculae near the cartilages of the growth zone are denser and their red colour is deeper, namely on the diaphyseal end of the bone. Compact bones, on the contrary, colour less intensively. In contrast to the red colour of the bones is the white colour of the periosteum and articular cartilage or insertion of tendons and ligaments, and also the white colour of the bone marrow in the marrow cavity of the diaphysis. The fine bone trabeculae penetrating through the marrow cavity in the bone marrow are stained red. After staining the sections of short and flat bones with alizarin red we can observe very well the relationships among the bone trabeculae of the spongy bone, marrow cavities, periosteum, and articular cartilage on the bone surface. On sections of bones of juvenile animals also the cartilaginous segments as yet not ossified can be well distinguished and in them possibly originating apophyseal ossification centres. In order to study the whole bones differentiation staining with alizarin red was used also for complete surface staining of the juvenile skull or juvenile pelvis. After a complete peeling off of the periosteum the surface of the bones was stained using the method described. On the stained pelvis of a ca 3-month old pig (Fig. 7) we can clearly see the outline of the individual pelvic bones and the cartilage of the growth zones of the apophysal ossification centre of the ischial eminence. Unstained remain also the cartilaginous parts of the juvenile pelvis in the pelvic symphysis and on the ischial eminence. On topographic sections of the extremities the staining method using alizarin red was successfully applied to indicate the individual bones on the section and their topographic interrelations and arrangement in the individual joints. On topographic sections of the joints the white articular cartilage, ligaments, articular capsule and syndesmotic connections of bones contrast with the red stained bone. On sagittal sections of the metapodium and toes of the dog staining shows the sesamoid bones of the toe, including the ossa sesamoidea dorsalia and the relationships among the claw bone, claw corium and its horny capsule. Differentiation staining of bone tissue gave very good results also for expressing the bones on the cross sections of the extremities, especially of distal parts, namely in combination with injections of the vessels with coloured injection masses. In the same way this method can be used for serial macrosections of the dog penis after injecting the vessels of the penis with coloured injection masses. The os penis is stained and contrasts with the other tissues. 


\section{Discussion}

The method of surface staining of bone tissue with alizarin red follows from the verified methods of Johns on (1933), Williams (1943), and Hood and Neil (1948) using the tinction affinity of alizarin red to the mineral component of the bone. This method is suitable in studies of the developmental stages of the skeleton, especially in the postnatal period in studies of larger objects where complete clarification of the tissues is not possible. The results of staining can be compared with the surface differential tinction method of the grey matter of the CNS according to Mulligan (1931) as concerns both the contrast of colours and the illustrative value. The alizarin colouring agent is bound to the surface of the bone only, or to the section of the bone and penetrates into the finer trabeculae of the spongy bone better than into compact bone. When staining preparations for 24 hours the bone becomes only slightly red in colour. However, also the differences in the intensity of the staining become visible. Especially in the surroundings of the growth zones of bones where the concentration of mineral substances is higher is the intensity of the red staining more expressive. It would, undoubtedly, be very interesting to perform - as regards the relationship to the intensity of the colour - quantitative investigations and comparisons of the content of mineral substances in the different parts of the bone. As compared with an X-ray picture the surface of the bone stained in this way would not be affected by the difference in the thickness of the part of the bone studied. By re-staining the bone, either by extending the time of the staining, or by increasing the concentration of the alizarin red solution, we can obtain the required higher colour contrast. If some dispersed patches stained with alizarin red are found in the soft tissues as well, it is the consequence of the imperfect removal of bone particles - scattered over the surrounding tissues when preparing sections using a bone saw which are stained with alizarin. The alkalic preserving fluids preserve the red-violet colouring of the bones. The staining of bones was tested on many anatomic preparations; the author, however, does not consider the possibilities given in this paper to be exhausted.

\section{Příspěvek $k$ využití diferenciačního barvení kostí na anatomických preparátech}

Navrženou barvící metodu kostní tkáně na makroskopických anatomických preparátech (Červený 1972) jsme vyzkoušeli a aplikovali pro účely výzkumu topografické anatomie, makrostruktury kostí $\mathrm{v}$ ontogenese a pro účely demonstrační ve výuce normální anatomie kostry savců. Upozorňujeme na možnosti využití této metody při studiu jednotlivých tělních krajin. Pro výuku normální anatomie savců lze touto metodou zajistit názorné preparáty makrostruktury kostí a topografických celků skeletu. Možno zhotovit série preparátů zachycujících vývojové změny struktury skeletu, a to i v kombinaci s rentgenografií. Vhodně lze využít barevné diferenciace kostí též při barevné fotodokumentaci. 


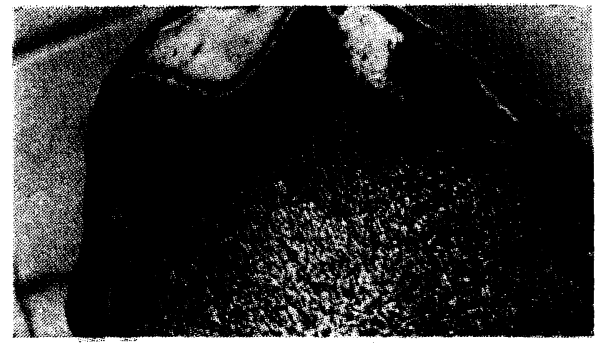

Fig. 1.

Cross section of the distal epiphysis of the femur of adult cattle. The white bone marrow, articular cartilage and fatty connective tissue contrast with the red colour of the bone spongiosa.

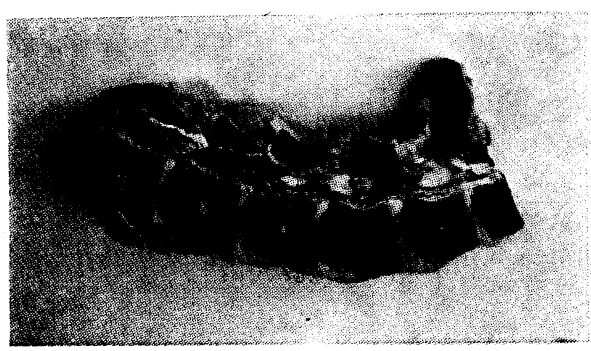

Fig. 2.

Sagittal section of the cervical spine of a onemonth old calf. The white intervertebral discs, cartilages of the growth zones of secondary ossification centres of the vertebral corpora and lig. suspensorium durae matris contrast with the redl coloured section surface of the vertebral arch, spinae and ossified parts of vertebral corpora. In the centre of the vertebral corpora the white bone marrow and developing central marrow cavity are distinguished in colour from the red bone spongiosa. The bone around the cartilages of the growth zone in the vertebral corpora is of deeper red.

Fig. 5.

Sagittal section of the sternum of a bullock of about two and a half years of age. The red sternebrae and sternal end of the first rib contrast with the white cartilaginous parts of the sternum and the rib.

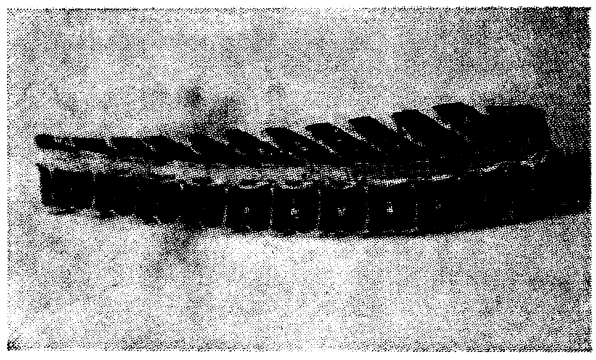

Fig. 3.

Sagittal section of the thoracic spine of a juvenile pig.

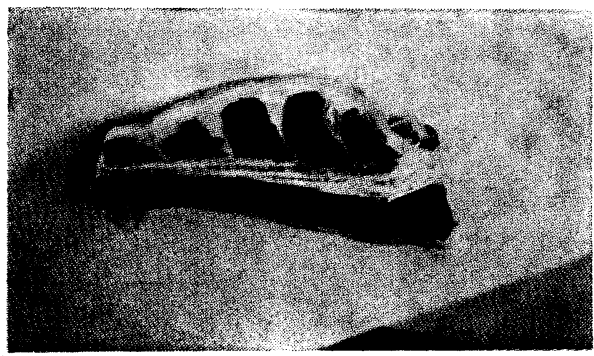

Fig. 4.

Sagittal section of the sacral bone of a juvenile pig. The corpora of the sacral vertebrae are connected, the intervertebral discs are reduced. The growth cartilages of cranial and caudal secondary ossification centres of the sacral vertebrae are preserved and ensure the longitudinal growth of the sacral bone.

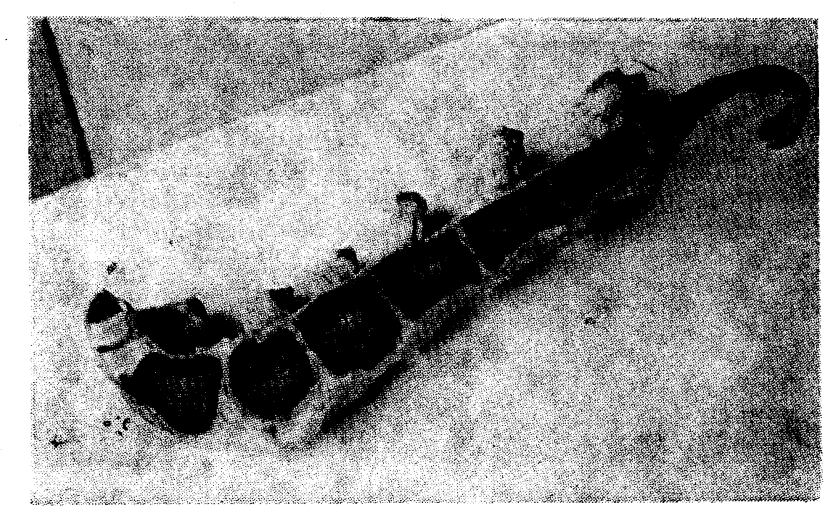


Fig. 6.

Cross section of the nasal and oral cavities of a juvenile pig. The red coloured bone demarcation of the nasal cavity is interrupted in places by the white zig-zag course of the connective tissue of sutures. In the medial plane of the section evident is the relationship between the cartilaginous nasal septum and the vomer. The red coloured cutting surface of the bony lamella of the ventral nasal concha contrasts with the mucous surface of the concha. On the section of the lower jaw detected are the roots of incisors in the teeth alveoli with the white periodontium and teeth pulp contrasting in colour with the red coloured dentin, cementum and bone of the teeth alveoli.
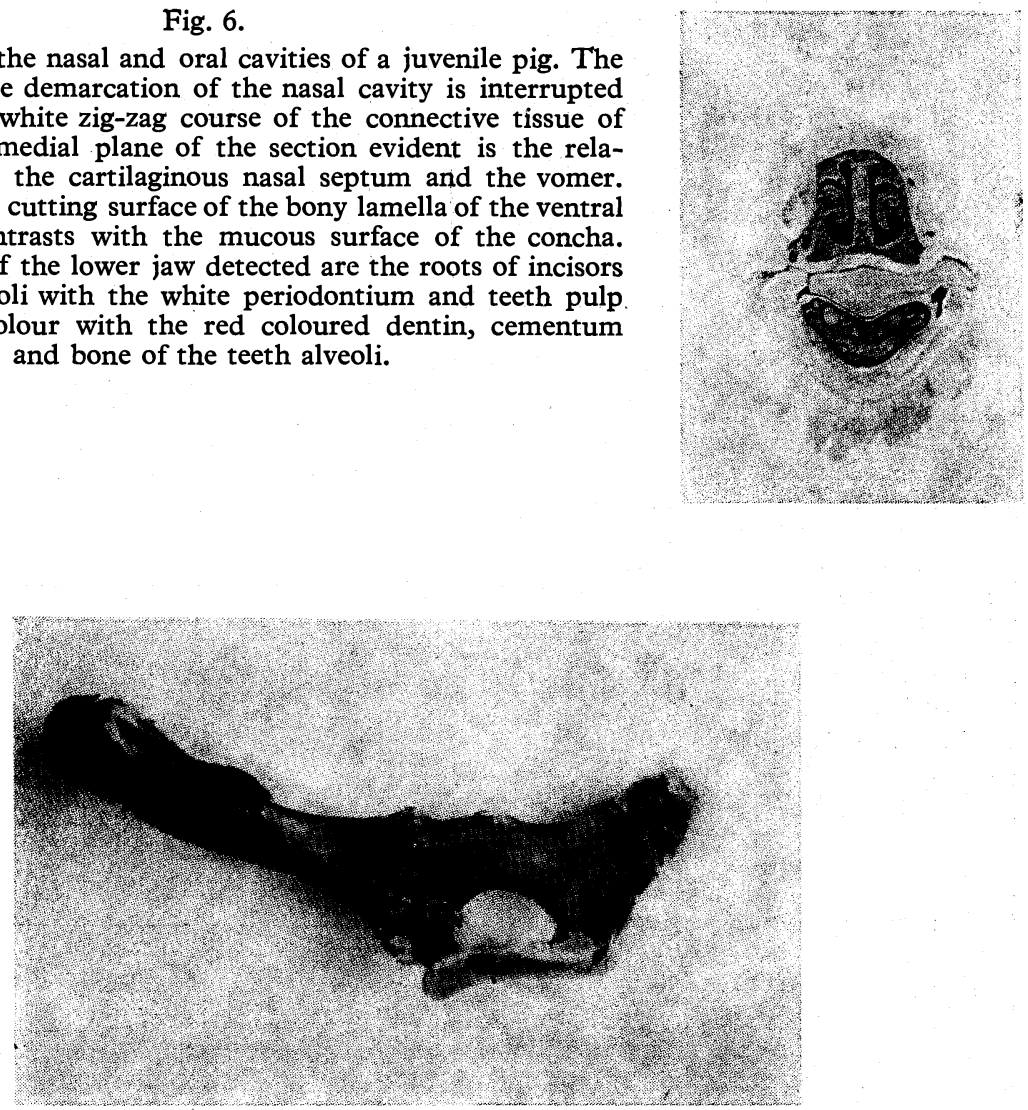

Fig. 7.

Surface staining of the pelvis of a juvenile pig. In the place of the unstained growth cartilages outlined are the margins of the individual pelvic bones and apophyseal ossification centres.

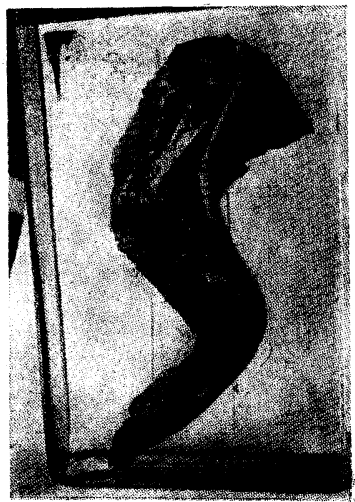

Fig. 8

Sagittal section of the thoracic extremity of a juvenile pig fixed in a measuring cell as an anatomic preparation. 

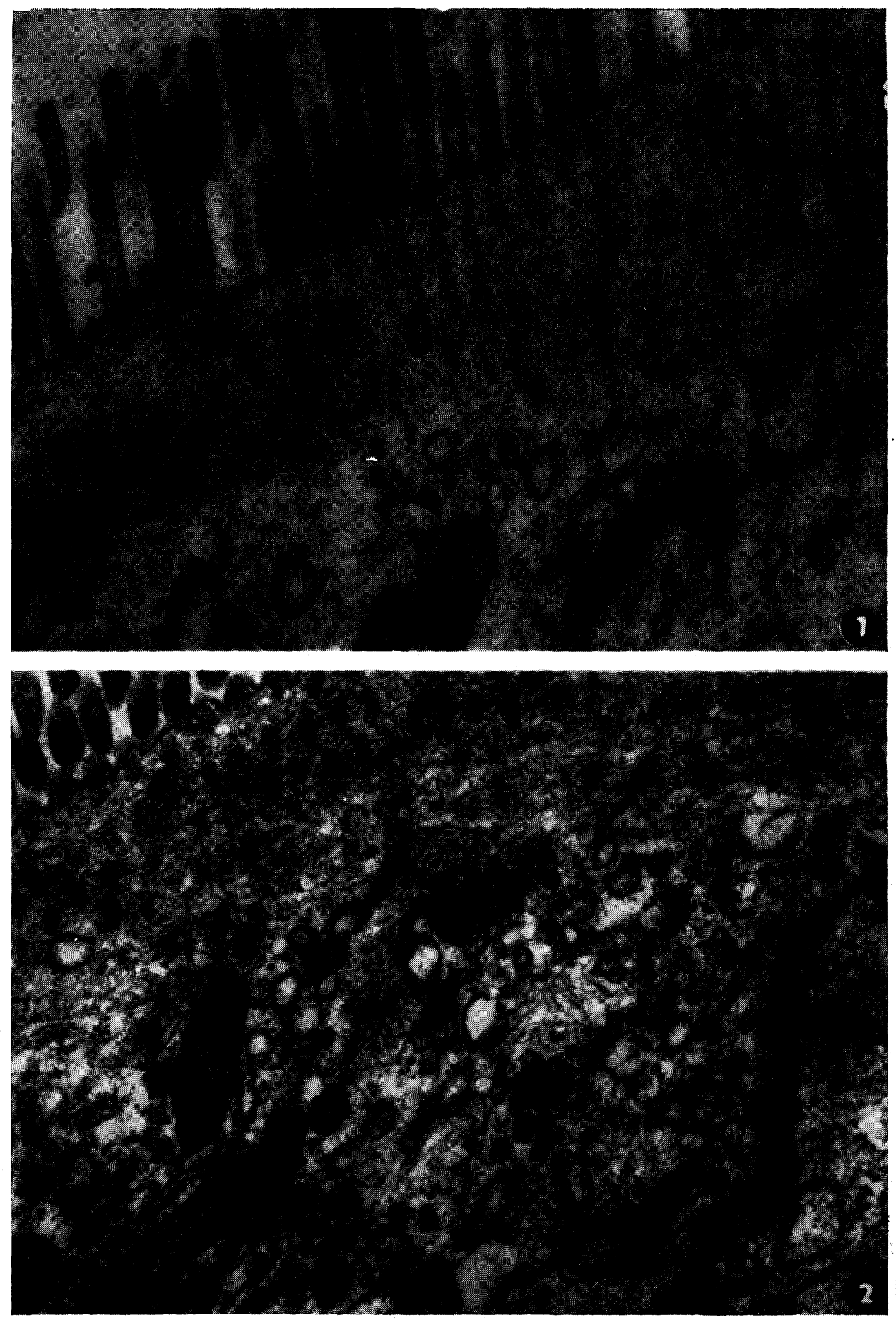

Fig. 1.

Fasted chick. Brush border with the area of terminal web of the enterocyte. Pinocytotic vesicles are present in the terminal web and between the profiles of the smooth endoplasmic reticulum below the terminal web. $\times 35,000$.

Fig. 2.

Fasted chick. Terminal web with the pinocytotic vesicles. In the apical part of enterocyte considerable amount of transparent vesicles of the smooth endoplasmic reticulum is visible. $\times 35000$. 

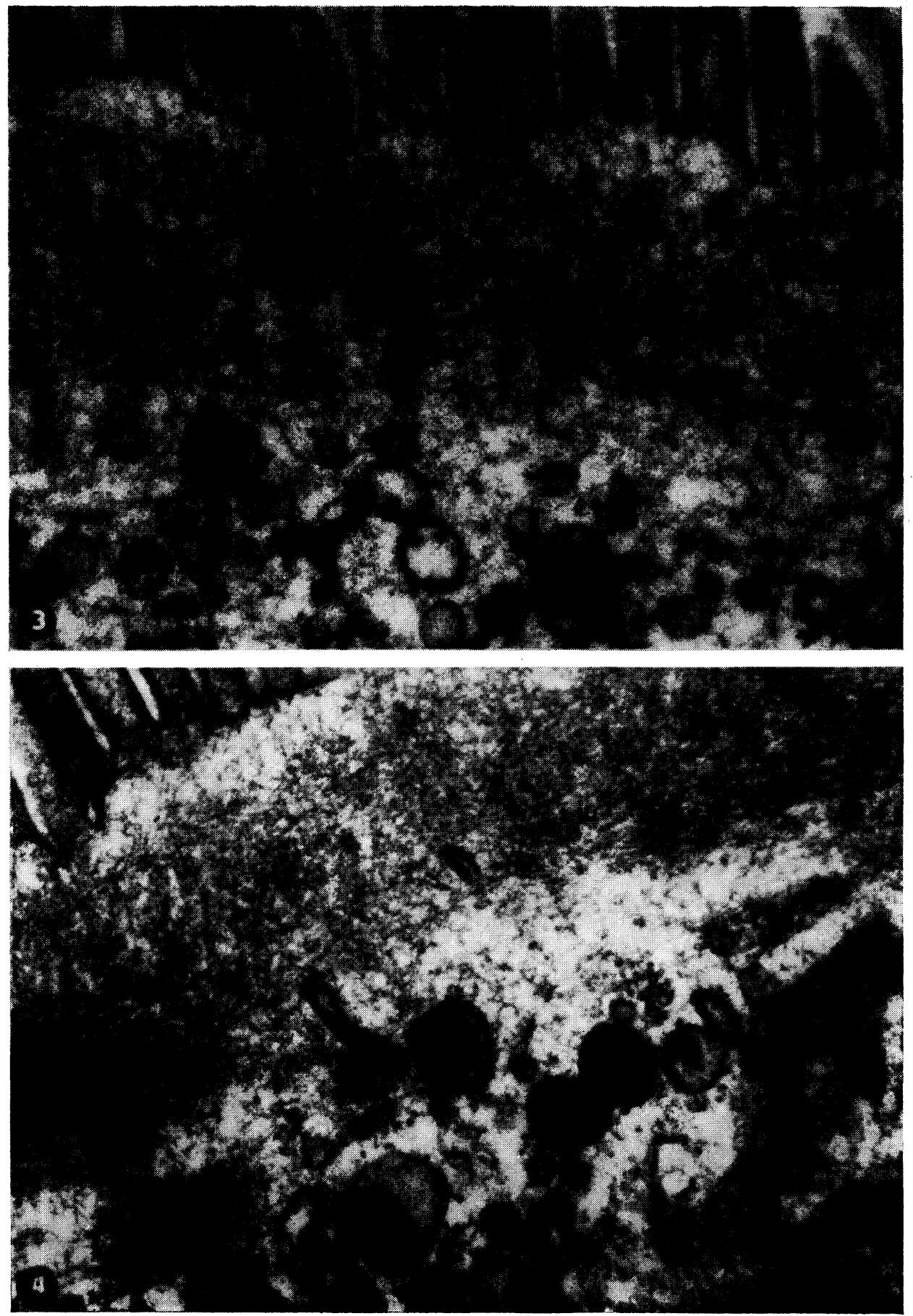

Fig. 3 and 4.

Chick 60 minutes after administration of sunflower oil. Pinocytotic vesicles in the terminal web and in the area of apical cytoplasm below the terminal web do not contain lipid droplets. In the vesicles of the smooth endoplasmic reticulum chylomicrons are visible. Both electronograms 


\section{К проблематике использования различительной окраски костей анатомических препаратов}

Предложенный метод окраски костной ткани макроскопических анатомических препаратов (Červený 1972) нами проверялся и использовался в области исследования топографической анатомии, макроструктуры костей в онтогенезе и с целью демонстрации в процессе обучения нормальной анатомии скелета млекопитающих. Внимание обращается на возможность использования данного метода в процессе изучения отдельных частей тела. Для изучения нормальной анатомии скелета млекопитающих можно с использованием упомянутого метода создать наглядные препараты макроструктуры костей и топографических частей скелета. Можно изготовить серии препаратов, отражающих изменения в развитии структуры скелета, в добавок, в комбинации с рентгенографией. Подходячим образом можно использовать световой дифференциации костей также в случа е цветной фотодокументации.

\section{References}

BATSON, O. V.: The differential staining of bone. Anat. Rec., 22, 1921: 159-164.

BRASH, J. C.: Some problems in the growth and developmental mechanics of bone. Edinburgh Med. J., 41, 1934: 363-387.

CERVENÝ, C.: Differentiation staining of bone tissue on topographic anatomic sections with alizarin red. Acta vet. Brno, 41, 1972: 303-307.

DŽIVANJAN, K. A.: O prižizněnoj okraske alizarinom kostnoj tkani u kurinnych embryonov. Izv. akd. nauk armjansk. SSR, 17, 1964: 85-88.

HOOD, R. C. W. S. - NEILL, W. M.: A modification of alizarin red "S" technique for demonstrating bone formation. Stain Technol., 23, 1948: 209-218.

JOHNSON, M. L.: The time and order of appearance of ossification centers in the albino mouse. Amer. J. Anat., 52, 1933: 241-272.

LILLIE, R. D.: Histopathologic technic and practical histochemistry. McGraw-Hill Book Company, New York 1965, (pp. 436-437).

MULLIGAN, J.: A method of staining the brain for macroscopic study. J. anat., 65, 1931: 82-85.

PUCHTLER, H. - MELOAN, S. N. - TERRY, M. S.: On the history and mechanism of alizarin and alizarin red S stains for calcium. J. Histochem. Cytochem., 17, 1969: 110-124.

WILLIAMS, T. W.: The use of sodium alizarine monosulphate and toluidin blue for the differential staining of bone and cartilage in toto. Anat. Rec., 76, 1943: 96-102. 